\title{
Prevalence of a single fish-pathogenic Saprolegnia sp. clone in Finland and Sweden
}

\author{
Eakaphun Bangyeekhun ${ }^{1}$, Päivi Pylkkö ${ }^{2}$, Pia Vennerström ${ }^{3}$, Henry Kuronen ${ }^{4}$, \\ Lage Cerenius ${ }^{1, *}$ \\ ${ }^{1}$ Department of Comparative Physiology, Evolutionary Biology Centre, Uppsala University, Norbyvägen 18A, \\ 75236 Uppsala, Sweden \\ ${ }^{2}$ Finnish Game and Fisheries Research Institute/Laukaa Aquaculture and Fisheries Research, Vilppulantie 415, \\ 41360 Valkola, Finland \\ ${ }^{3}$ National Veterinary and Food Research Institute, PO Box 45, 00581 Helsinki, Finland \\ ${ }^{4}$ National Veterinary and Food Research Institute, Oulu Regional Unit, PO Box 517, 90101 Oulu, Finland
}

\begin{abstract}
Thirty-one isolates of Saprolegnia sp., most originating from infected salmon or trout, were characterised genetically and physiologically. The majority (6 of 31) of the isolates from several widely separated geographical locations was found to be genetically almost identical as assessed by RAPD-PCR. The remaining isolates belonged to 3 different groups with 1 to 3 representatives each. It is suggested that the first group of isolates represents a virulent form of the organism that has been widely spread by clonal propagation. The ability to repeated zoospore emergence, as an alternative to direct germination, seems to characterise specific Saprolegnia genotypes that may have adapted to certain hosts.
\end{abstract}

KEY WORDS: Saprolegnia - Saprolegniosis · Fish disease $\cdot$ Random amplification of polymorphic DNA RAPD $\cdot$ Repeated zoospore emergence

\section{INTRODUCTION}

During recent years, outbreaks of saprolegniosis, the disease caused by Saprolegnia spp., in freshwater fishes have become common in Scandinavia. These outbreaks have severely affected farmed salmonids, and have occasionally been encountered in fishes in natural freshwater bodies of Finland and Sweden. The gross sign of the disease typically displays as a relatively superficial, cotton-wool like, white growth of mycelia on the fish skin, especially around the head, dorsal and caudal fins, gills, in the muscular layer and internal organs (Khoo 2000, Grandes et al. 2001, Hussein et al. 2001). Even though Saprolegnia sp. could infect many fish species, outbreaks of saprolegniosis are frequently found among salmonid species and their eggs (Hatai \& Hoshiai 1992, Noga 1993, DiéguezUribeondo et al. 1996, Bruno \& Wood 1999, Hussein et al. 2001) and in farmed channel catfish Ictalurus punc- tatus (Durborow et al. 1991, Bly et al. 1992, Bangyeekhun et al. 2001).

Several species of Saprolegnia have been found to be pathogenic to fishes (Noga 1993). Taxonomical identification of Saprolegnia sp. using classical criteria is based on morphology of the reproductive structures, i.e. antheridia, oogonia and oospores (Willoughby 1978, Neish \& Hughes 1980). However, many fishpathogenic Saprolegnia isolates usually do not develop any sexual stages when cultured in vitro and therefore cannot be taxonomically classified (Beakes \& Ford 1983, Grandes et al. 2000). Characterisation of fishpathogenic Saprolegnia is useful for the furtherance of epidemiological studies of the source of infection, disease transmission, disease spreading and control of the disease. Some morphological and physiological studies have made it possible to classify different subgroups of Saprolegnia isolates. In an ultrastructural study of secondary cyst morphology, Grandes et al. (2000) distin- 
guished the fish lesion isolates from the water isolates, and Beakes (1983) was able to identify $S$. parasitica from $S$. diclina. Variation in esterase isoenzyme patterns (Beakes \& Ford 1983) and differences in radial growth rate (Willoughby \& Copland 1984, Hatai et al. 1990) have been used for determining distinct groups of fish lesion isolates. Restriction fragment length polymorphisms (RFLPs) are useful for classification of Saprolegnia and could distinguish $S$. parasitica from $S$. diclina (Molina et al. 1995). Also, random amplification of polymorphic DNA polymerase chain reaction (RAPD-PCR; Welsh \& McClelland 1990, Williams et al. 1990) has been applied for analysis of the fish pathogenic Saprolegnia genome (Diéguez-Uribeondo et al. 1996, Bangyeekhun et al. 2001). This latter method provides a sensitive and rapid assay for the assessment of genetic distance between different isolates.

In the present study, we applied the RAPD-PCR technique and the presence or absence of repeated zoospore emergence to characterise Saprolegnia sp. isolates obtained from Finland and Sweden to investigate the epidemiology of the saprolegniosis in this region. We found that the majority of the isolates belonged to a single genetically defined group that probably has been widely spread by clonal propagation.

\section{MATERIALS AND METHODS}

Saprolegnia strains. Thirty-one isolates of Saprolegnia spp. were isolated from infected tissue of the brown trout Salmo trutta m. lacustris, trout $S$. trutta, whitefish Coregonus lavaretus, rainbow trout Oncorhynchus mykiss, brook trout Salvelinus fontinalis, landlocked salmon Salmo salar m. sebago, salmon S. salar, noble crayfish Astacus astacus, and pond water from 6 different locations in Finland and 1 location in Sweden. The isolates from Finland are designated FinX, where X is the isolation number and the isolates from Sweden are designated Swe203 and Swe239 (see Table 1). The following reference isolates were used for comparison: $S$. parasitica (Spt) isolated from freshwater crayfish Astacus leptodactylus (Söderhäll et al. 1991), S. parasitica (Spt 198A) isolated from brown trout Salmo trutta (Diéguez-Uribeondo et al. 1996), Saprolegnia parasitica (Spt ACTT \# 42062/ TP41; formerly named $S$. diclina Type 3 by Willoughby 1978), Saprolegnia sp. (CF91-1, CF96-2 and CF98-8) isolated from channel catfish (Bly et al. 1992, Bangyeekhun et al. 2001) and $S$. diclina (Sdi 2003h). All isolates were maintained on PG-1 agar medium (Unestam 1965).

Repeated zoospore emergence. Repeated zoospore emergence was performed according to the method described by Diéguez-Uribeondo et al. (1994b). Briefly, mycelia were grown in PG-1 drop cultures for $3 \mathrm{~d}$ at $20^{\circ} \mathrm{C}$. To trigger sporulation, the mycelia were washed 3 times with sterile lake water and then incubated in petri dishes containing lake water for $14 \mathrm{~h}$ at $20^{\circ} \mathrm{C}$ to allow release of zoospores. The swimming zoospores were transferred to the test tubes, which then were agitated in a vortex mixer for $45 \mathrm{~s}$ to obtain synchronous encystment. The release of secondary zoospores was observed under the microscope after incubating the cyst suspension at $20^{\circ} \mathrm{C}$ for $150 \mathrm{~min}$.

DNA extraction. A small piece of mycelium (approximately $1.5 \mathrm{mg}$ dry weight) grown in PG-1 drop culture was inoculated in a $100 \mathrm{ml}$ flask containing $25 \mathrm{ml}$ PG-1 medium and cultured with shaking at $20^{\circ} \mathrm{C}$. After $3 \mathrm{~d}$, the mycelia were harvested, washed with sterile water, and ground in liquid nitrogen with a mortar. The total genomic DNA was extracted according to the method described by Lee \& Taylor (1990). The DNA extracts were stored at $-20^{\circ} \mathrm{C}$ until required.

RAPD-PCR. The PCR reactions were carried out in $25 \mu \mathrm{l}$ volumes containing $100 \mathrm{ng}$ genomic DNA, $10 \mathrm{mM}$ Tris-HCl (pH 8.6), $50 \mathrm{mM} \mathrm{KCl}, 1.5 \mathrm{mM} \mathrm{MgCl}_{2}, 0.1 \%$ Triton X-100, 0.2 mM each of dNTPs (Amersham Pharmacia Biotech), $0.4 \mu \mathrm{M}$ random primer, 1.5 Units of Taq DNA polymerase (GibcoBRL) and 1.5 Units of Platinum Taq Antibody (GibcoBRL). Nine nucleotide primers (Operon) were used: A04 (5'-AATCGGGCTG-3'), A07 (5'-GAAACGGGTG-3'), A09 (5'-GGGTAACGCC-3'), A10 (5'-GTGATCGCAG-3'), A12 (5'-TCGGCGATAG-3'), B01 (5'-GTTTCGCTCC-3'), B05 (5'-TGCGCCCTTC-3'), B11 (5'-GTAGACCCGT-3'), and B15 (5'-GGAGGGTGTT-3'). Each PCR reaction was run with a negative control containing no DNA. Amplifications were performed in a Perkin Elmer GeneAmp PCR system 9700 programmed for 1 cycle of initial denaturation at $94^{\circ} \mathrm{C}$ for $5 \mathrm{~min}, 45$ cycles of denaturation at $94^{\circ} \mathrm{C}$ for $1 \mathrm{~min}$, annealing at $36^{\circ} \mathrm{C}$ for $1 \mathrm{~min}$ and extension at $72^{\circ} \mathrm{C}$ for $2 \mathrm{~min}$, and a final extension at $72^{\circ} \mathrm{C}$ for $7 \mathrm{~min}$. The PCR products were separated on $1.4 \%$ agarose gel, and 100 bp ladder DNA (Amersham Pharmacia Biotech) and lambda DNA/HindIII were used as molecular weight markers. Gels were stained with ethidium bromide, visualised by UV illumination and photographed.

Data analysis. RAPD-PCR was performed at least twice and only reproducibly amplified markers were scored as present (1) or absent (0). Similarity coefficients $(F)$ between 2 isolates were calculated according to the formula of Nei \& Li (1979): $F=2 N_{x y} / N_{x}+N_{y \prime}$ where $N_{x y}$ is the number of common fragments between 2 isolates, and $N_{x}$ and $N_{y}$ are the number of fragments in Isolate $x$ and $y$, respectively. Pooled data from 9 primers were used for this calculation. The dendrogram was constructed from the similarity values obtained from pairwise similarity among all isolates as described by Fegan et al. (1993). 


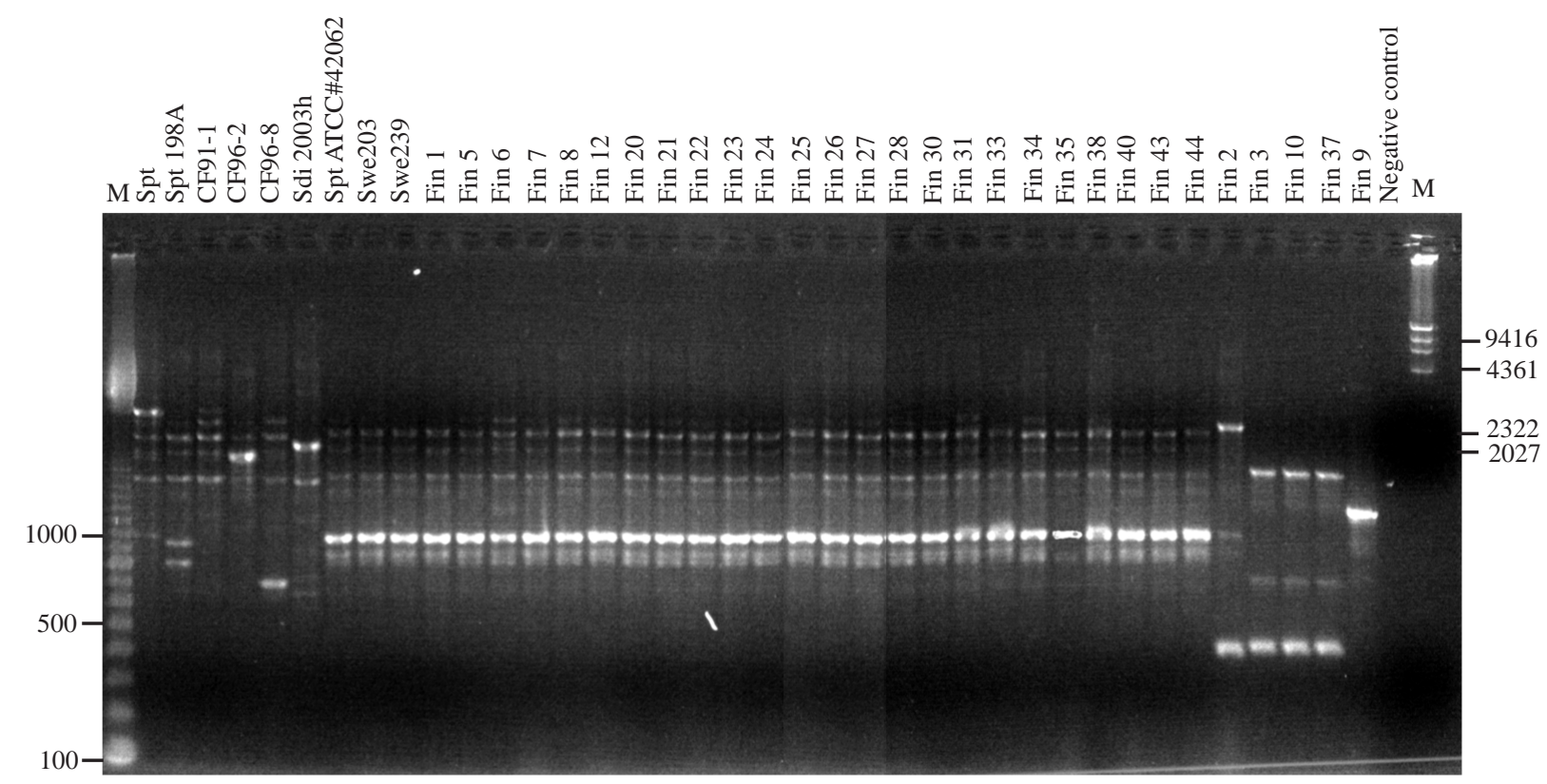

Fig 1. Saprolegnia spp. Amplification of genomic DNA from different isolates using Primer B15. M: molecular weight markers; $100 \mathrm{bp}$ DNA ladder marker is on the left and lambda DNA/HindIII on the right. Abbreviations as in Table 1

\section{RESULTS AND DISCUSSION}

\section{Characterisation of Saprolegnia sp. isolates based on RAPD analysis}

Nine primers, which gave consistent results and produced a reasonable number of identifiable and polymorphic bands, were used for RAPD analysis. The amplification pattern of the PCR products from independent genomic DNA preparations of each isolate was consistent. Pooled data from 9 primers gave a total of 1010 clearly amplified PCR bands in 109 different positions, the average number of bands per isolate was 26.6. The size of the fragments produced ranged from 0.3 to $30 \mathrm{~kb}$ and there were 70 of 109 positions, i.e. $62.2 \%$, with a product size larger than $1 \mathrm{~kb}$. An example of an RAPD pattern generated by Primer B15 is shown in Fig. 1.

All PCR fragments obtained were used for genetic distance analysis. The dendrogram constructed from the pairwise similarity among all Saprolegnia sp. isolates demonstrates that the tested isolates of Saprolegnia sp. (Table 1) are genetically different from the reference isolates, except for Spt ATCC \# 42062, and can be grouped into 4 distinct groups (Fig. 2). Within each group, members share more than $80 \%$ similarity of the RAPD band pattern; i.e. the average similarity of Group 1 was $95.9 \%$ and that of Group 3 was $100 \%$. In addition, clusters of $100 \%$ identity were found; i.e. Cluster 1a: Fin 1, Fin 5, Fin 6, Fin 8, Fin 23 and Fin 28; Cluster 1b: Fin 20 and Fin 22; Cluster 1c: Fin 21 and Fin 26; Cluster 1d:
Similarity index

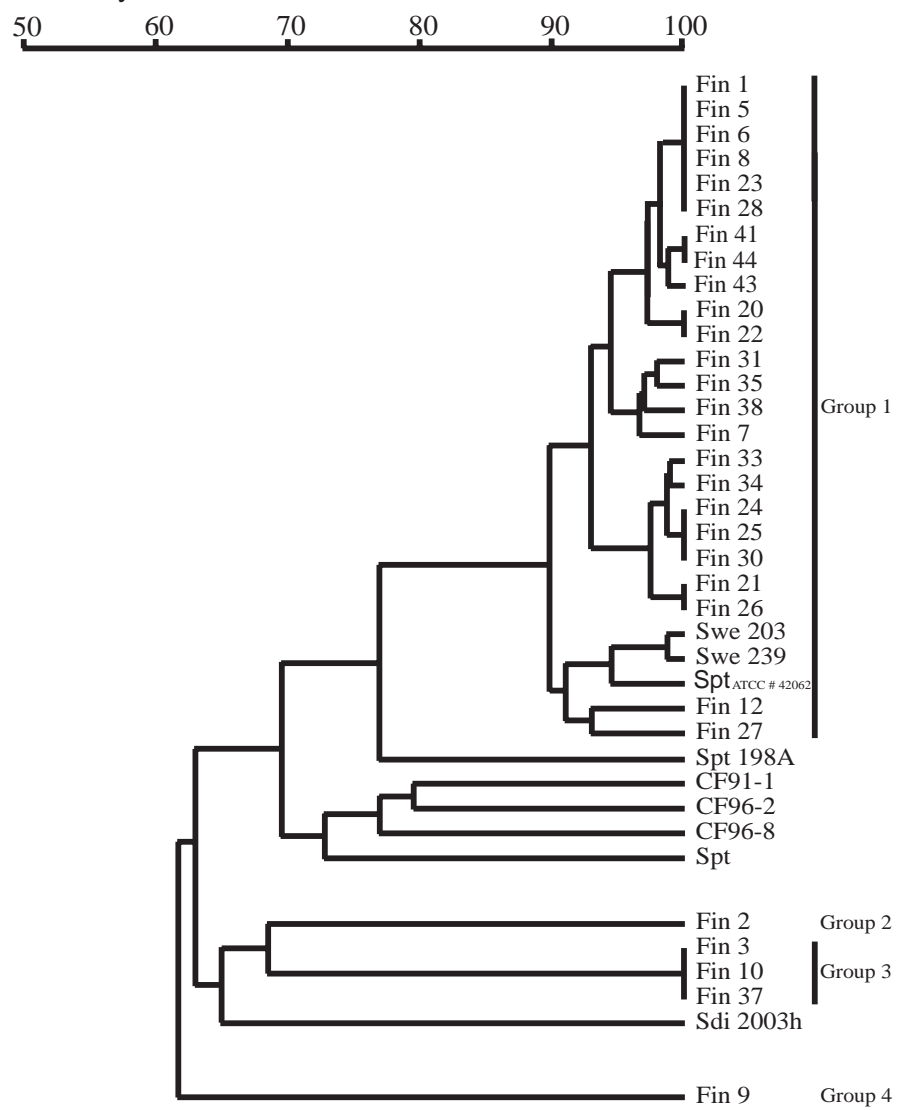

Fig 2. Saprolegnia spp. Dendrogram of 35 isolates based on RAPD dataset. Abbreviations as in Table 1 
Fin 24, Fin 25 and Fin 30; Cluster 1e: Fin 3, Fin 10 and Fin 37; Cluster 3a: Fin 3, Fin 10 and Fin 37 (Fig. 2).

Group 1, the largest group, contained 26 of 31 isolates, which were sampled from several salmonid species or sources of pond water from 1995 to 2001, and Spt ATCC \# 42062 (Table 1, Fig. 2). The spread of Group 1 is demonstrated by its presence in 6 of 7 examined locations at least $50 \mathrm{~km}$ apart (Fig. 3). Thus, a group of closely related strains has prevailed for over $7 \mathrm{yr}$ in widely separated geographical localities, suggesting that its members are capable of causing persis- tent infections to fishes. It seems likely that Group 1 is dominant among isolates at Laukaa. It is interesting that a cluster of $100 \%$ similarity (Cluster 1a) was isolated from 4 geographically separated locations and in different years (Table 1). One of the reference strains, Spt ATCC \# 42062, fell into Group 1. This strain is a pathogen of brown trout Salmo trutta, and was isolated from Cumbria, UK (Willoughby et al. 1983). This implies that the members of Group 1 occur in many areas, although more specimens from different areas must be examined to confirm this.

Table 1. Saprolegnia spp. Isolates used for RAPD-PCR analysis and their repeated zoospore emergence (RZE) performance. Germ: germination; Fin: Finland; Swe: Sweden; Spt: Saprolegnia parasitica; Sdi: S. diclina; CF: Saprolegnia sp.

\begin{tabular}{|c|c|c|c|c|c|c|c|}
\hline \multicolumn{2}{|c|}{ RAPD group Isolate } & \multirow[t]{2}{*}{ Location } & \multirow{2}{*}{$\begin{array}{c}\text { Year } \\
\text { of isolation }\end{array}$} & \multirow[t]{2}{*}{ Source } & \multicolumn{2}{|c|}{$\%$ Germ or RZE } & \multirow{2}{*}{$\begin{array}{c}\text { Zoospore } \\
\text { generations }\end{array}$} \\
\hline \multicolumn{4}{|l|}{ First clade } & & & & \\
\hline & Fin1 & Rautalampi & 2000 & Salmo trutta m. lacustris & Germ & $95.4 \pm 1.5$ & 1 \\
\hline & Fin 5 & Helsinki & 1999 & Salmo trutta m. lacustris & Germ & $96.6 \pm 0.9$ & 1 \\
\hline & Fin 6 & Laukaa & 1999 & Pond water & Germ & $95.1 \pm 0.6$ & 1 \\
\hline & Fin 8 & Laukaa & 1999 & Coregonus lavaretus & Germ & $94.1 \pm 0.6$ & 1 \\
\hline & Fin 23 & Laukaa & 1999 & Salmo salar & Germ & $94.6 \pm 1.2$ & 1 \\
\hline & Fin 28 & Paltamo & 2000 & Salmo salar & Germ & $93.7 \pm 1.3$ & 1 \\
\hline & Fin 20 & Laukaa & 1998 & Salmo trutta m. lacustris & Germ & $93.2 \pm 0.8$ & 1 \\
\hline & Fin 22 & Laukaa & 1998 & Salmo trutta m. lacustris & Germ & $93.9 \pm 1.0$ & 1 \\
\hline & Fin 40 & Tervo & 2001 & Oncorhynchus mykiss & Germ & $95.3 \pm 1.8$ & 1 \\
\hline & Fin 44 & Tervo & 2001 & Oncorhynchus mykiss & Germ & $96.7 \pm 1.2$ & 1 \\
\hline & Fin 43 & Tervo & 2001 & Salmo trutta m. lacustris & Germ & $93.2 \pm 0.9$ & 1 \\
\hline & Fin 7 & Paltoma & 2000 & Salmo trutta m. lacustris & Germ & $95.7 \pm 1.9$ & 1 \\
\hline & Fin 31 & Paltamo & 2000 & Salmo trutta m. lacustris & Germ & $96.5 \pm 2.0$ & 1 \\
\hline \multirow[t]{13}{*}{ Group $1-$} & Fin 35 & Paltamo & 1996 & Salvelinus fontinalis & Germ & $96.2 \pm 0.6$ & 1 \\
\hline & Fin 38 & Paltamo & 2000 & Salmo trutta m. lacustris & Germ & $94.9 \pm 0.8$ & 1 \\
\hline & Fin 21 & Laukaa & 1998 & Salmo trutta m. lacustris & Germ & $91.2 \pm 1.7$ & 1 \\
\hline & Fin 26 & Laukaa & 2000 & Salmo trutta & Germ & $95.4 \pm 0.9$ & 1 \\
\hline & Fin 24 & Laukaa & 1999 & Salmo trutta & Germ & $92.9 \pm 1.8$ & 1 \\
\hline & Fin 25 & Laukaa & 1999 & Salmo trutta & Germ & $93.5 \pm 2.1$ & 1 \\
\hline & Fin 30 & Laukaa & 2000 & Salmo trutta m. lacustris & Germ & $95.3 \pm 2.4$ & 1 \\
\hline & Fin 33 & Laukaa & 2000 & Pond water & Germ & $97.9 \pm 0.8$ & 1 \\
\hline & Fin 34 & Paltamo & 1996 & Salmo salar m. sebago & Germ & $97.9 \pm 0.7$ & 1 \\
\hline & Fin 12 & Laukaa & 2000 & Salmo trutta m. lacustris & Germ & $94.4 \pm 1.4$ & 1 \\
\hline & Fin 27 & Laukaa & 2000 & Salmo trutta & Germ & $96.4 \pm 2.9$ & 1 \\
\hline & Swe 203 & Umeå & 1995 & Salmo salar & Germ & $94.4 \pm 2.0$ & 1 \\
\hline & Swe 239 & Umeå & 1995 & Salmo trutta & Germ & $95.0 \pm 0.5$ & 1 \\
\hline Ref. strain & Spt ATCC\#42062 & UK & 1978 & Salmo trutta & Germ & $98.8 \pm 1.3$ & 1 \\
\hline Ref. strain & Spt 198A & Spain & 1996 & Salmo trutta & Germ & $93.3 \pm 2.0$ & 1 \\
\hline Ref. strain & Spt & Turkey & 1990 & Astacus leptodactylus & RZE & $98.2 \pm 3.4$ & 4 \\
\hline Ref. strain & CF91-1 & USA & 1991 & Ictalurus punctatus & RZE & $98.1 \pm 2.9$ & 4 \\
\hline Ref. strain & CF96-2 & USA & 1996 & Ictalurus punctatus & RZE & $98.4 \pm 2.4$ & 4 \\
\hline Ref. strain & CF96-8 & USA & 1996 & Ictalurus punctatus & RZE & $98.3 \pm 4.1$ & 4 \\
\hline \multicolumn{8}{|l|}{ Second clade } \\
\hline \multirow[t]{2}{*}{ Group 2} & Fin 2 & Paltoma & 2000 & Salmo salar m. sebago & Germ & $94.3 \pm 1.8$ & 1 \\
\hline & Fin 3 & Paltoma & 1999 & Pond water & RZE & $94.1 \pm 1.4$ & 4 \\
\hline \multirow[t]{2}{*}{ Group $3 \dashv$} & Fin 10 & Paltoma & 1999 & Pond water & RZE & $95.5 \pm 0.6$ & 4 \\
\hline & Fin 37 & Temmesjok & 1999 & Astacus astacus & RZE & $94.4 \pm 1.0$ & 4 \\
\hline Ref. strain & Sdi2003h & UK & & Saprophyte & Germ & $94.6 \pm 2.3$ & 1 \\
\hline \multicolumn{8}{|l|}{ Third clade } \\
\hline Group 4 & Fin 9 & Rautalampi & 2000 & Salmo salar & RZE & $92.8 \pm 2.3$ & 4 \\
\hline
\end{tabular}




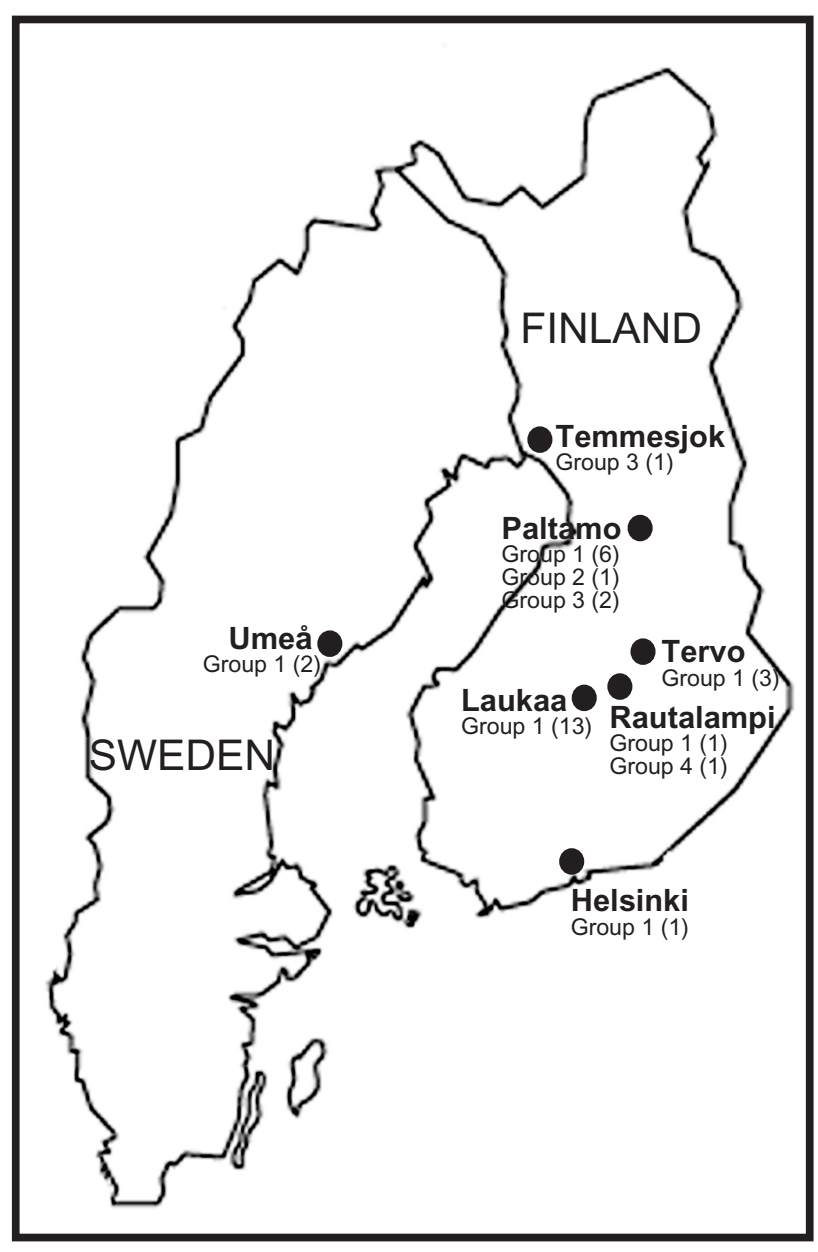

Fig 3. Map of Finland and Sweden showing location of sampling and distribution of Saprolegnia sp. isolates. Number in parentheses indicates number of isolates in each group (see Table 1)

Groups 2, 3 and 4 were minor groups containing 1 or 3 Saprolegnia sp. isolates per group. Group 2 was represented by a single isolate of Fin 2. Group 3 consisted of Fin 3, Fin 10 and Fin 37 with $100 \%$ similarity, whereas Group 4 was represented by Fin 9. Group 2 and Group 4 were obtained from infected fishes at Paltamo and Rautalampi, respectively. The members of Group 3 were isolated from pond water at Paltamo (Fin 3 and Fin 10) and from noble crayfish Astacus astacus at Temmesjok (Fin 37), demonstrating at least a limited spread of this genotype. Söderhäll et el. (1991) isolated S. parasitica (Spt) from a Turkish specimen of the freshwater crayfish $A$. leptodactylus that was able to infect and kill 3 different species of crayfishes, i.e. A. astacus, Pacifastacus leniusculus and Procambarus clarkii (Diéguez-Uribeondo et al. 1994a). This Spt isolate was also included in this study as one of reference strains. The RAPD analysis indicated that Spt and Fin
37 are different genotypes. Therefore, this study indicates that there are at least 2 genotypes of Saprolegnia that may parasitize crayfishes although Saprolegnia spp. are so far known only as severe pathogens of fishes.

Except for Sdi2003h, the isolates in this study did not reproduce sexually in the laboratory, and thus could not be distinguished to species level. Therefore, it is possible that the 4 distinct RAPD groups do not belong to the same species. Based on RAPD analysis, the dendrogram clearly separates the isolates into 3 different clades (Fig. 2), with the first clade composed of Group 1, Spt, Spt ACTT \# 42062, Spt 198A and catfish isolates, the second clade of Groups 2 and 3 and Sdi 2003h, and Fin 9 constituting a third clade. Hence, we propose that the closely related strains of Group 1 are plausibly Saprolegnia parasitica and the closely related strains of Groups 2 and 3 may be $S$. diclina.

Applying the RAPD-PCR technique, DiéguezUribeondo et al. (1996) demonstrated the spread of a group of closely related strains of Spanish Saprolegnia parasitica isolated from infected trout, and Bangyeekhun et al. (2001) showed the presence of 3 genetically distinct groups of catfish isolates of Saprolegnia sp. in Mississippi. In this study, we included the Spanish S. parasitica (Spt 198A) and 3 isolates of American Saprolegnia sp. (CF91-1, CF96-2 and CF96-8; 1 isolate of each group) to compare with Finnish and Swedish Saprolegnia sp. isolates. The RAPD analysis showed that the genetic similarity of both Finnish and Swedish isolates to Spanish and American isolates is less than $80 \%$ (Fig. 2). The genotype variation among Saprolegnia sp. isolates observed in our study also suggests that there is genetic dissimilarity of fish pathogenic Saprolegnia from different geographic locations, i.e. Northern Europe, Southern Europe and USA.

\section{Repeated zoospore emergence}

Repeated zoospore emergence is the capacity of an encysted spore to release a new zoospore generation instead of germinating. The members of Groups 3 and 4, and Spt CF91-1, CF96-2 and CF96-8 could produce about 90 to $95 \%$ secondary zoospores of the primary cysts, and these isolates could produce 4 generations of zoospores. However, the members of Groups 1 and 2, and Spt 198A, Spt ATCC \# 42062 and Sdi 2003h underwent germination instead. In Isolate Spt 198A, we found that the germlings of encysted spores formed short hyphae, about 3 to 5 cyst diameters in length, and then terminated their growth. This result agrees with a previous report by Diéguez-Uribeondo et al. (1996). Cysts of zoospores from several species of Saprolegniales are able to release new generations of zoospores 
instead of germinating. Cerenius \& Söderhäll (1985) demonstrated that repeated zoospore emergence is a specific mechanism for a pathogenic Aphanomyces species and proposed this mechanism to be an adaptation to a parasitic mode of life. Several isolates of Saprolegnia sp. in this study and the trout isolates of Saprolegnia parasitica as reported by DiéguezUribeondo et al. (1996) did not exhibit repeated zoospore emergence. Thus, repeated zoospore emergence is not a specific phenomenon for fish-pathogenic Saprolegnia isolates since some pathogenic isolates exhibit germination after encystment. However, the result clearly indicates that repeated zoospore emergence is correlated to certain genotypes of Saprolegnia spp. The number of zoospore generations of Spt was shown to depend on the length of time the zoospore was allowed to swim (Diéguez-Uribeondo et al.1994b). It could produce 4 to 6 zoospore generations after zoospores of each generation were kept swimming for 15,60 or $240 \mathrm{~min}$, respectively. In this study, the zoospores of tested and reference isolates, which exhibited repeated zoospore emergence (including Spt), were allowed to swim for 150 min in each generation, and they could produce 4 zoospore generations. Hence, our study indicates that the relationship between the length of swimming time and maximal number of zoospore generations in Saprolegnia isolates is similar, although the isolates are genetically different (Table 1).

Variations of oogonium morphology (Willoughby 1978), esterase enzyme profiles (Beakes \& Ford 1983) and cyst ornamentation (Grandes et al. 2000) have been used to distinguish subgroups of Saprolegnia parasitica. In this study, a relationship between zoospore behavior and host-specificity was observed. Except for Fin 9, the zoospores of salmonid isolates exhibit germination, whereas the zoospores of nonsalmonid (catfish and crayfish) isolates perform repeated zoospore emergence (Table 1).

In summary, RAPD analysis suggested that there are at least 4 groups of Saprolegnia playing a pathogenic role in saprolegniosis in Scandinavia. The dominance of Group 1 over a large geographical area implies that it may represent a high virulent clone of Saprolegnia. Although repeated zoospore emergence is clearly not specific for pathogenic Saprolegnia spp., it is present in certain groups of isolates defined by genotype and host-specificity, and can be useful in distinguishing subgroups of pathogenic Saprolegnia. The virulence of the different subgroups remains to be clarified.

Acknowledgements. Dr. Riitta Rahkonen and Dr. Päivi Eskelinen are thanked for discussions. E.B. was funded by a scholarship from the Royal Thai Government, and L.C. by a grant from Carl Tryggers Stiftelse.

\section{LITERATURE CITED}

Bangyeekhun E, Quiniou SMA, Bly JE, Cerenius L (2001) Characterisation of Saprolegnia sp. isolates from channel catfish. Dis Aquat Org 45:53-59

Beakes G (1983) A comparative account of cyst ontogeny in saprophytic and fish-lesion (pathogenic) isolates of the Saprolegnia diclina-parasitica complex. Can J Bot 61: 603-625

Beakes GW, Ford H (1983) Esterase isozyme variation in genus Saprolegnia, with particular reference to the fishpathogenic Saprolegnia diclina-parasitica complex. J Gen Microbiol 129:2605-2619

Bly JE, Lawson LA, Dale DJ, Szali AJ, Durborow RM, Clem LW (1992) Winter saprolegniosis in channel catfish. Dis Aquat Org 13:155-164

Bruno DW, Wood BP (1999) Saprolegnia and other Oomycetes. In: Woo PTK, Bruno DW (eds) Fish disease and disorders, Vol 3. Viral, bacterial and fungal infections. CABI Publishing, CAB International, Wallingford, Oxon, p 599-659

Cerenius L, Söderhäll K (1985) Repeated zoospore emergence as a possible adaptation to parasitism in Aphanomyces. Exp Mycol 8:370-377

Diéguez-Uribeondo J, Cerenius L, Söderhäll K (1994a) Saprolegnia parasitica and its virulence on three different species of freshwater crayfish. Aquaculture 120:219-228

Diéguez-Uribeondo J, Cerenius L, Söderhäll K (1994b) Repeated zoospore emergence in Saprolegnia parasitica. Mycol Res 98:810-815

Diéguez-Uribeondo J, Cerenius L, Söderhäll K (1996) Physiological characterisation of Saprolegnia parasitica isolates from brown trout. Aquaculture 140:247-257

Durborow RM, Taylor PW, Crosby MD, Santucci TD (1991) Fish mortality in Mississippi catfish farming industry in 1988: causes and treatments. J Wildl Dis 27:144-147

Fegan M, Manners JM, Maclean DJ, Irwin JAG, Samuels KDZ, Holdom DG, Li DP (1993) Random amplified polymorphic DNA markers reveal a high degree of genetic diversity in the entomopathogenic fungus Metarhizium anisopliae var anisopliae. J Gen Microbiol 139:2075-2081

Grandes JMF, Díez MF, Gancedo JMA (2000) Ultrastructural analysis of Saprolegnia secondary zoospore cyst ornamentation from infected wild brown trout, Salmo trutta L., and river water indicates two distinct morphotypes amongst long-spined isolates. J Fish Dis 23:147-160

Grandes JMF, Díez MF, Gancedo JMA (2001) Experimental pathogenicity in rainbow trout, Oncorhychus mykiss (Walbaum), of two distinct morphotypes of long-spined Saprolegnia isolates obtained from wild brown trout, Salmo trutta L., and river water. J Fish Dis 24: 351-359

Hatai K, Hoshiai GI (1992) Mass mortality in cultured coho salmon (Oncorrychus kisutch) due to Saprolegnia parasitica Coker. J Wildl Dis 28:532-536

Hatai K, Willoughby LG, Beakes GW (1990) Some characteristics of Saprolegnia obtained from fish hatcheries in Japan. Mycol Res 94:182-190

Hussein M, Hatai K, Nomura T (2001) Saprolegniosis in salmonids and their eggs in Japan. J Wildl Dis 37:204-207

Khoo L (2000) Fungal diseases in fish. Semin Avian Exot Pet 9:102-111

Lee SB, Taylor JW (1990) Isolation of DNA from fungal mycelia and single spores. In: Innis MA, Gelfand DH, Sninsky JJ, White TJ (eds) PCR protocols: a guide to methods and applications. Academic Press, San Diego, p 282-287

Molina FI, Jong SC, Ma G (1995) Molecular characterization and identification of Saprolegnia by restriction analysis of 
genes coding for ribosomal RNA. Antonie Leeuwenhoek 68:65-74

Nei M, Li WH (1979) Mathematical model for studying genetic variation in terms of restriction endonuclease. Proc Natl Acad Sci USA 76:5269-5273

Neish GA, Hughes GC (1980) Fungal diseases of fish. TFH Publication, Neptune, NJ

Noga EJ (1993) Water mold infection of fresh water fish: recent advances. Annu Rev Fish Dis 3:291-304

Söderhäll K, Dick MW, Clark G, Fürst M, Constantinescu O (1991) Isolation of Saprolegnia parasitica from the crayfish Astacus leptodactylus. Aquaculture 92:121-125

Unestam T (1965) Studies on the crayfish plague fungus Aphanomyces astaci I. Some factors affecting growth in vitro. Physiol Plant 18:483-505

Editorial responsibility: David Bruno,

Aberdeen, Scotland, UK
Welsh J, McClelland M (1990) Fingerprinting genomes using PCR with arbitrary primers. Nucleic Acids Res 18: 7213-7218

Williams JGK, Kubelik AR, Livak KJ, Rafalski JA, Tingey SV (1990) DNA polymorphisms amplified by arbitrary primers are useful as genetic markers. Nucleic Acids Res 18: 6531-6535

Willoughby LG (1978) Saprolegnias of salmonid fish in Windermere: a critical analysis. J Fish Dis 1:51-67

Willoughby LG, Copland JW (1984) The temperature-growth relationships of Saprolegnia pathogenic to fish, especially eels cultivated in warm water. Nova Hedwigia 39:35-55

Willoughby LG, McGroy, CB, Pickering AD (1983) Zoospore germination of Saprolegnia pathogenic to fish. Trans $\mathrm{Br}$ Mycol Soc 80:421-435

Submitted: April 27, 2002; Accepted: July 24, 2002 Proofs received from author(s): December 12, 2002 